\title{
KEMAMPUAN PEMBENTUKAN GEL SURIMI MANYUNG (Arius spp.) PADA BERBAGAI KONDISI PEMANASAN DAN PENCUCIAN
}

\section{GELLING ABILITY OF MANYUNG (Arius spp.) SURIMI UNDER DIFFERENT HEATING AND WASHING CONDITIONS}

\author{
Iwan Y.B. Lelana dan Amir Husni*)
}

\begin{abstract}
Manyung is one of low value fish in Yogyakarta. In order to increase the value, manyung was processed into surimi. In this research, manyung was processed into surimi with different heating temperatures $\left(40,45,50,55,60\right.$, and $\left.70^{\circ} \mathrm{C}\right)$ and washing time frequency $(0,1,2,3$, 4 , and 5 times) to investigate the gel properties of manyung surimi.

Gel strength of manyung surimi increased as washing time treatment increased from 0 to 5 times. Statistical analysis showed that the 4 washing time and 5 washing time have similar gel strength and sensory characteristics. Manyung surimi with 5 washing time and preincubation at $60^{\circ} \mathrm{C}$ followed by cooking at $90^{\circ} \mathrm{C}$ produced the highest gel strength.
\end{abstract}

Key words : Gelling ability, Manyung (Arius spp.), Surimi

\section{Pengantar}

Manyung (Arius spp.) merupakan salah satu jenis ikan laut yang banyak ditangkap di Pantai Selatan Daerah Istimewa Yogyakarta. Hasil penelitian yang dilakukan atas kerjasama antara Dinas Perikanan DIY dengan Pusat Studi Sumberdaya dan Teknologi Kelautan UGM yang dilaksanakan di TPI (Tempat Pendaratan Ikan) Pandansimo menunjukkan bahwa hasil tangkapan ikan ini rata-rata per bulan adalah $729,4 \mathrm{~kg}$. Namun apabila dilihat dari segi ekonomi ternyata harganya jauh lebih rendah dari hasil tangkapan lainnya (Anonim, 2000).

Manyung, sebagaimana produk akuatik lainnya, merupakan bahan pangan yang mudah sekali mengalami kerusakan. Kerusakan ini dapat terjadi secara biokimia maupun secara mikrobiologis. Adanya proses-proses ini telah dirasakan sangat menghambat usaha pemasaran dan tidak jarang menimbulkan kerugian besar. Oleh karena itu perlu dilakukan upaya untuk meningkatkan daya simpan dan daya awet hasil perikanan tersebut melalui proses pengolahan dan pengawetan, salah satunya dengan mengolahnya menjadi surimi.

Surimi merupakan suatu produk berbentuk daging lumat mentah berasal dari ikan yang sudah dipisahkan dari tulangnya secara mekanis, dicuci dengan air es kemudian dicampur dengan menambahkan cryoprotectant untuk mendapatkan daya simpan yang baik selama penyimpanan beku (Huda dkk., 1999). Surimi dapat digunakan sebagai bahan untuk berbagai produk makanan yang populer seperti bakso ikan, mie ikan, sausage ikan, burger ikan maupun kue ikan. Di samping itu surimi juga dapat diolah menjadi produk tiruan (analog) makanan laut seperti udang, kepiting, scallop atau lobster. Pada umumnya surimi diolah dari ikan-ikan yang tidak atau kurang mempunyai nilai ekonomis atau dari ikan-ikan yang pemanfaatannya belum optimal.

Salah satu sifat penting dari surimi adalah kemampuannya membentuk gel yang dipengaruhi oleh jenis ikan, formula dalam pembuatan, dan prosedur pemanasan. Di antara berbagai faktor ini, prosedur

\footnotetext{
*) Staf Pengajar Jurusan Perikanan Fakultas Pertanian UGM, Jalan Sosio Justisia, Bulaksumur, Yogyakarta
} 
pemanasan merupakan salah satu tahapan yang dapat dikontrol dalam rangka memperbaiki mutu gel surimi namun sangat dipengaruhi oleh jenis ikan. Kondisi pemanasan yang ideal untuk surimi sangat bervariasi tergantung pada jenis ikan. Dalam rangka mengetahui kondisi pemanasan yang ideal untuk surimi manyung maka dilakukan penelitian ini.

\section{Bahan dan Metode}

Bahan penelitian yang diperlukan antara lain: Manyung dalam bentuk segar yang diperoleh dari TPI Pandansimo Bantul Yogyakarta, garam $(\mathrm{NaCl})$, sodium tripolifosfat (STPP) atau polifosfat, sukrosa, sorbitol.

Peralatan yang diperlukan dalam penelitian ini antara lain: pisau, telenan, plastik, styrofoam, freezer, pengaduk, gilingan daging, silinder aluminium, water bath, dan seperangkat alat untuk analisis kekuatan gel.

\section{Pembuatan surimi dan perlakuan}

Ikan dalam keadaan masih segar diambil dari TPI Pandansimo Bantul Yogyakarta kemudian dibawa ke laboratorium menggunakan styrofoam yang telah diisi es batu. Di laboratorium, ikan dibersihkan, disiangi dan diambil filetnya serta dipisahkan dari tulangnya secara manual. Setelah itu daging dihancurkan dengan penggiling daging dan dicuci sebanyak 0-5 kali menggunakan air es dengan perbandingan berat ikan : air es $=1: 2$. Selanjutnya daging yang telah dicuci dimampatkan (pressed) dengan alat pengepres. Selanjutnya ke dalam daging ikan yang telah dimampatkan ditambahkan STPP sebanyak $0,2 \%$, sukrosa $4 \%$, dan sorbitol $4 \%$ yang dicampur secara merata ke dalam massa daging ikan. Setelah tahap ini surimi siap diperlakukan sesuai desain. Secara singkat proses pembuatan surimi dan persiapan sampel tersebut dapat dilihat pada Gambar 1.

\section{Pengamatan}

Pengamatan dilakukan di Laboratorium Rekayasa Pangan PAU Pangan dan Gizi UGM dan Laboratorium Teknologi Pengolahan Hasil Perikanan Jurusan Perikanan Fakultas Pertanian UGM.

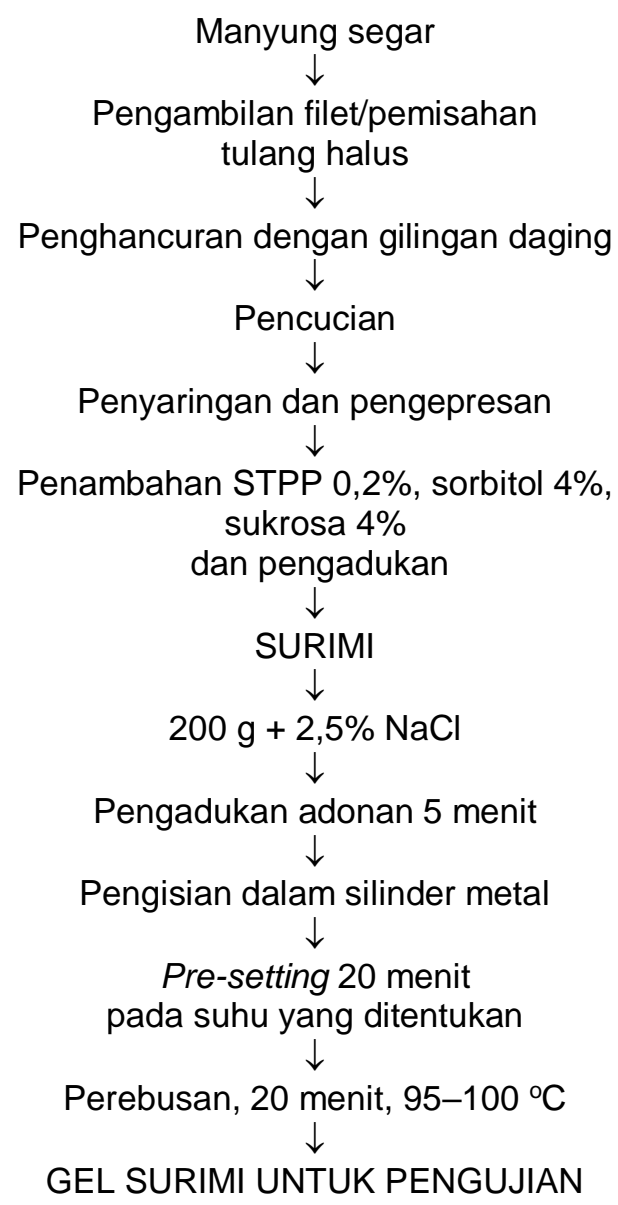

Gambar 1. Skema pembuatan gel surimi untuk pengujian

Dalam penelitian ini dilakukan perlakuan frekuensi pencucian $(0,1,2,3,4$, dan 5 kali) dan penggunaan variasi suhu presetting untuk mengetahui kisaran suhu modori surimi. Perlakuan frekuensi pencucian meliputi tanpa pencucian $(A)$, pencucian satu kali (B), dua kali (C), tiga kali (D), empat kali $(E)$, dan lima kali $(F)$. Variasi suhu pre-setting terdiri dari tujuh level suhu yaitu suhu $40,45,50,55,60$, 
65 , dan $70^{\circ} \mathrm{C}$. Masing-masing perlakuan diulang tiga kali.

Pengamatan yang dilakukan meliputi uji kekuatan gel dengan uji Folding Test (Hanafiah dan Malawat, 1995), uji sensoris (Soekarto, 1985; Kartika dkk., 1988), uji kadar protein dengan metode Mikro Kjeldahl (Sudarmadji dkk., 1996), uji kadar lemak dengan Soxhlet (Wodman 1941 dalam Sudarmadji dkk., 1997) dan uji kadar air dengan metode Oven (AOAC, 1970).

\section{Analisis hasil}

Data yang diperoleh dianalisis varian menggunakan CRD (Completely Randomized Design) untuk uji sifat sensoris atau organoleptik (kenampakan, warna, dan bau), sifat fisik (uji lipat dan kekuatan gel), dan kimiawinya (kandungan protein, air, dan lemak), sedangkan untuk uji kesukaan dianalisis varian menggunakan RCBD (Randomized Completely Block Design). Apabila ada beda nyata dilanjutkan dengan uji LSD (Least Significant Difference) dengan tingkat signifikansi $\alpha=5 \%$ (Gomez and Gomez, 1984).

\section{Hasil dan Pembahasan}

\section{Kekuatan gel}

Pengujian kekuatan gel surimi manyung menggunakan metode uji lipat (folding test) pada berbagai tingkat pemanasan pendahuluan (suhu pre-setting) dan frekuensi pencucian dapat dilihat pada Gambar 2, sedangkan nilai folding test dengan suhu pre-setting $40^{\circ} \mathrm{C}$ dapat dilihat pada Tabel 1. Dari gambar tersebut dapat dilihat bahwa kekuatan gel surimi manyung pada umumnya meningkat dengan meningkatnya frekuensi pencucian. Hal ini menunjukkan bahwa dengan bertambahnya frekuensi pencucian dapat meningkatkan kekuatan gel yang terbentuk. Peningkatan kekuatan gel ini disebabkan karena meningkatnya konsentrasi protein miofibril pada surimi dengan pencucian daging lumat tiga, empat, dan lima kali. Protein miofibril bersifat tidak larut dalam air tetapi larut dalam larutan garam encer (Irianto 1990). Konsentrasi miofibril yang tinggi ini dapat meningkatkan konsentrasi aktin dan miosin. Aktin dan miosin dalam larutan garam (pengamatan gel dilakukan dengan menambah garam $2,5 \% \mathrm{~b} / \mathrm{b}$ ) akan larut dan membentuk sol yang karena pengaruh pemanasan akan terbentuk gel yang elastis.

Gambar 2 menunjukkan bahwa gel surimi manyung pada umumnya stabil pada suhu $40-50^{\circ} \mathrm{C}$. Hal ini sesuai dengan yang dikatakan Fennema (1985), bahwa daging ikan yang ditambahkan garam akan menghasilkan pasta aktomiosin dan apabila dipanaskan pada suhu sekitar $50^{\circ} \mathrm{C}$ akan menghasilkan pasta produk surimi dengan gel yang baik, tetapi apabila suhu pemanasan dinaikkan menjadi $60^{\circ} \mathrm{C}$ maka surimi yang dihasilkan akan menurun kekuatan gelnya dan dihasilkan produk surimi yang lunak atau tidak elastis.

Tabel 1. Nilai folding test surimi manyung

\begin{tabular}{ccc}
\hline Perlakuan & $\begin{array}{c}\text { Nilai } \\
\text { Folding } \\
\text { Test }\end{array}$ & $\begin{array}{c}\text { Tingkat } \\
\text { Mutu }\end{array}$ \\
\hline Tanpa pencucian (A) & $2^{a}$ & $\mathrm{C}$ \\
Pencucian 1 kali (B) & $3^{b}$ & $\mathrm{~B}$ \\
Pencucian 2 kali (C) & $4^{c}$ & $\mathrm{~A}$ \\
Pencucian 3 kali (D) & $4^{c}$ & $\mathrm{~A}$ \\
Pencucian 4 kali (E) & $4^{c}$ & $\mathrm{~A}$ \\
Pencucian 5 kali (F) & $4^{c}$ & $\mathrm{~A}$ \\
\hline
\end{tabular}

Keterangan : Angka yang ditandai dengan huruf yang berbeda menunjukkan ada beda nyata 


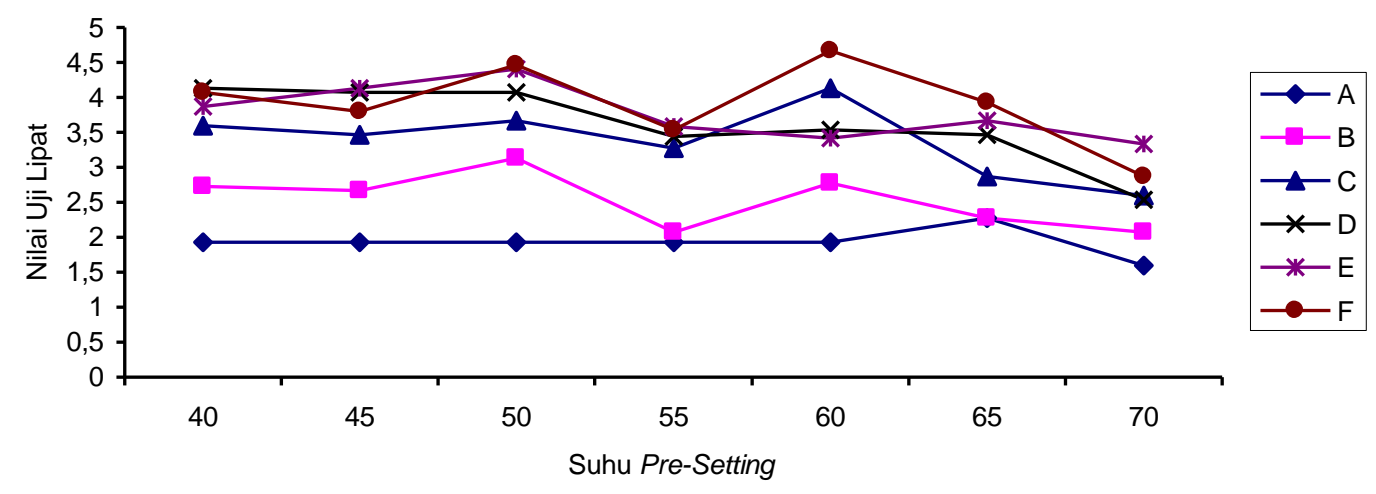

Keterangan:
$A=$ Tanpa pencucian
$C=$ Pencucian dua kali
$\mathrm{E}=$ Pencucian empat kali
$B=$ Pencucian satu kali
$\mathrm{D}=$ Pencucian tiga kali
$\mathrm{F}=$ Pencucian lima kali

Gambar 2. Kekuatan gel surimi manyung pada berbagai suhu pre-setting dan frekuensi pencucian

Tabel 1 menunjukkan adanya beda nyata $(\alpha=0,05)$ antara perlakuan tanpa pencucian daging lumat dengan perlakuan pencucian daging lumat. Pencucian daging lumat satu kali berbeda nyata $(\alpha=0,05)$ dengan pencucian daging lumat dua, tiga, empat, dan lima kali. Hal ini disebabkan pada perlakuan pencucian daging lumat dua kali protein sarkoplasma sebagian besar sudah larut dalam air sehingga konsentrasi protein miofibril surimi tinggi. Sedangkan pada pencucian daging lumat tiga, empat, dan lima kali protein sarkoplasma yang masih dapat larut hanya kecil sehingga konsentrasi protein miofibril surimi tidak jauh berbeda dengan perlakuan pencucian daging lumat dua kali.

\section{Kadar air, lemak, dan protein}

Kadar protein dan lemak surimi manyung menunjukkan kecenderungan menurun dengan adanya perlakuan pencucian daging lumat satu, dua, tiga, empat, dan lima kali, meskipun tidak beda nyata $(\alpha=$ $0,05)$. Hal ini disebabkan selama pencucian daging lumat protein yang larut dalam air, senyawa-senyawa nitrogen (TMAO, urea, dan lain-lain), dan beberapa garam mineral ikan ikut terbuang pada proses pembuangan air. Demikian pula partikel-partikel lemak yang pada saat pencucian daging lumat dengan air dingin terapung di bagian permukaan juga terbuang pada proses pembuangan air sehingga kadar lemaknya menurun. Seperti dinyatakan Hennigar dkk. (1988), bahwa pencucian berkali-kali pada proses pengolahan gel ikan akan menghilangkan protein sarkoplasma yang dapat menghambat pembentukan gel, menghilangkan bau anyir, pigmen, dan lemak sehingga kandungan aktomiosin meningkat. Protein aktomiosin berpengaruh terhadap peningkatan kemampuan daging lumat dalam pembentukan gel.

Tabel 2 menunjukkan bahwa kadar protein kasar, lemak dan air surim manyung tidak ada beda nyata $(\alpha=0,05)$ antar perlakuan. Kadar protein kasar surimi manyung tidak mengalami penurunan yang signifikan pada perlakuan pencucian daging lumat satu, dua, tiga, empat, dan lima kali. Hal ini menunjukkan bahwa berdasarkan kadar proteinnya maka pengolahan manyung menjadi surimi tidak menurunkan nilai gizi secara nyata. 
Tabel 2. Kadar air, lemak dan protein kasar surimi manyung

\begin{tabular}{cccc}
\hline $\begin{array}{c}\text { Perla- } \\
\text { kuan }\end{array}$ & $\begin{array}{c}\text { Kadar } \\
\text { Protein } \\
\text { Kasar (\%) }\end{array}$ & $\begin{array}{c}\text { Kadar } \\
\text { Lemak (\%) }\end{array}$ & $\begin{array}{c}\text { Kadar } \\
\text { Air (\%) }\end{array}$ \\
\hline A & $17,77^{a}$ & $1,36^{a}$ & $80,32^{a}$ \\
B & $14,76^{a}$ & $1,16^{a}$ & $83,41^{a}$ \\
C & $17,66^{a}$ & $0,93^{a}$ & $81,26^{a}$ \\
D & $19,29^{a}$ & $1,11^{a}$ & $78,53^{a}$ \\
E & $17,29^{a}$ & $1,13^{a}$ & $79,86^{a}$ \\
F & $15,87^{a}$ & $0,86^{a}$ & $82,32^{a}$ \\
\hline
\end{tabular}

Keterangan : Angka yang ditandai dengan huruf yang sama menunjukkan tidak ada beda nyata

Kandungan lemak dalam daging ikan dapat berpengaruh pula terhadap elastisitas surimi walaupun yang sangat menentukan adalah protein miofibril. Ikan yang berlemak tinggi biasanya mempunyai elastisitas yang rendah. Oleh karena itu, lemak perlu dipisahkan atau dicuci lebih dahulu. Kadar lemak yang tinggi (lebih dari dua persen) biasanya agak menyulitkan dalam proses pengolahan surimi (Suyuti dan Tambunan, 1974). Kadar lemak manyung dan surimi manyung dengan perlakuan pencucian daging lumat satu, dua, tiga, empat, dan lima kali, semuanya dibawah dua persen sehingga manyung dapat diolah menjadi surimi dan termasuk surimi yang berkualitas baik.

Pencucian daging lumat satu, dua, tiga, empat, dan lima kali menurunkan kadar lemak walaupun analisa variannya $(\alpha=$ 0,05 ) tidak berbeda nyata. Hal ini disebabkan pada proses pencucian daging lumat, lemak terapung di bagian permukaan air dapat terbuang pada saat penirisan daging lumat.

Kadar air surimi manyung selama pencucian daging lumat tidak menunjukkan kecenderungan tertentu. Hal ini kemungkinan disebabkan karena surimi sebagai bahan antara mempunyai kadar air yang bervariasi akibat sulitnya mengontrol kadar air daging lumat setelah proses pembuangan air. Kadar air surimi manyung berfluktuasi setelah proses pencucian daging lumat sampai lima kali yaitu $78,53-82,32 \%$

\section{Sifat organoleptik}

Tabel 3. Rerata nilai skoring kenampakan, warna, dan bau surimi manyung

\begin{tabular}{cccc}
\hline $\begin{array}{c}\text { Perla- } \\
\text { kuan }\end{array}$ & $\begin{array}{c}\text { Kenam- } \\
\text { pakan }\end{array}$ & Warna & Bau \\
\hline A & $1,84^{\mathrm{a}}$ & $1,72^{\mathrm{a}}$ & $1,44^{\mathrm{a}}$ \\
$\mathrm{B}$ & $3,33^{\mathrm{b}}$ & $3,89^{\mathrm{b}}$ & $2,83^{\mathrm{ab}}$ \\
C & $5,47^{\mathrm{c}}$ & $5,00^{\mathrm{c}}$ & $3,81^{\mathrm{bc}}$ \\
D & $4,81^{\mathrm{c}}$ & $4,67^{\mathrm{bc}}$ & $5,05^{\mathrm{cd}}$ \\
E & $5,55^{\mathrm{d}}$ & $7,06^{\mathrm{d}}$ & $6,20^{\mathrm{d}}$ \\
F & $6,96^{\mathrm{d}}$ & $7,13^{\mathrm{d}}$ & $6,61^{\mathrm{d}}$ \\
\hline
\end{tabular}

Keterangan : Angka yang ditandai dengan huruf yang berbeda menunjukkan ada beda nyata

Tabel 4. Nilai skoring kenampakan, warna, dan bau gel manyung

\begin{tabular}{cccc}
\hline $\begin{array}{c}\text { Perla } \\
\text { kuan }\end{array}$ & $\begin{array}{c}\text { Kenampa } \\
\text { kan }\end{array}$ & Warna & Bau \\
\hline A & $1,60^{\mathrm{a}}$ & $1,42^{\mathrm{a}}$ & $1,27^{\mathrm{a}}$ \\
B & $4,13^{\mathrm{b}}$ & $4,27^{\mathrm{b}}$ & $2,90^{\mathrm{b}}$ \\
C & $4,42^{\mathrm{b}}$ & $4,24^{\mathrm{b}}$ & $3,83^{\mathrm{b}}$ \\
D & $6,21^{\mathrm{c}}$ & $6,30^{\mathrm{c}}$ & $5,72^{\mathrm{c}}$ \\
E & $6,20^{\mathrm{c}}$ & $6,25^{\mathrm{c}}$ & $5,66^{\mathrm{c}}$ \\
F & $7,11^{\mathrm{d}}$ & $7,16^{\mathrm{d}}$ & $6,21^{\mathrm{c}}$ \\
\hline
\end{tabular}

Keterangan : Angka yang ditandai dengan huruf yang berbeda menunjukkan ada beda nyata 
Tabel 5. Nilai hedonik kenampakan, warna, bau, dan kesukaan secara keseluruhan surimi manyung

\begin{tabular}{ccccc}
\hline Perlakuan & Kenampakan & Warna & Bau & Kesukaan Keseluruhan \\
\hline A & $3,33^{\mathrm{a}}$ & $3,21^{\mathrm{a}}$ & $3,39^{\mathrm{a}}$ & $3,24^{\mathrm{a}}$ \\
B & $3,83^{\mathrm{b}}$ & $3,73^{\mathrm{b}}$ & $3,89^{\mathrm{b}}$ & $3,88^{\mathrm{b}}$ \\
C & $4,23^{\mathrm{c}}$ & $4,40^{\mathrm{c}}$ & $3,97^{\mathrm{b}}$ & $4,34^{\mathrm{c}}$ \\
D & $4,17^{\mathrm{c}}$ & $4,17^{\mathrm{c}}$ & $3,98^{\mathrm{b}}$ & $4,26^{\mathrm{c}}$ \\
E & $5,02^{\mathrm{d}}$ & $5,38^{\mathrm{d}}$ & $4,67^{\mathrm{c}}$ & $5,19^{\mathrm{d}}$ \\
F & $5,36^{\mathrm{e}}$ & $5,54^{\mathrm{d}}$ & $4,64^{\mathrm{c}}$ & $5,29^{\mathrm{d}}$ \\
\hline
\end{tabular}

Keterangan : Angka yang ditandai dengan huruf yang berbeda menunjukkan ada beda nyata

Tabel 6. Nilai hedonik kenampakan, warna, bau, dan kesukaan keseluruhan gel manyung

\begin{tabular}{ccccc}
\hline Perlakuan & Kenampakan & Warna & Bau & Kesukaan Keseluruhan \\
\hline A & $2,90^{\mathrm{a}}$ & $2,93^{\mathrm{a}}$ & $3,02^{\mathrm{a}}$ & $2,93^{\mathrm{a}}$ \\
$\mathrm{B}$ & $4,14^{\mathrm{b}}$ & $4,06^{\mathrm{b}}$ & $3,57^{\mathrm{b}}$ & $3,90^{\mathrm{b}}$ \\
$\mathrm{C}$ & $4,57^{\mathrm{b}}$ & $4,63^{\mathrm{c}}$ & $3,89^{\mathrm{bc}}$ & $4,40^{\mathrm{c}}$ \\
$\mathrm{D}$ & $4,68^{\mathrm{b}}$ & $4,78^{\mathrm{c}}$ & $4,34^{\mathrm{d}}$ & $4,57^{\mathrm{c}}$ \\
E & $5,86^{\mathrm{c}}$ & $5,21^{\mathrm{d}}$ & $3,99^{\mathrm{c}}$ & $4,93^{\mathrm{d}}$ \\
F & $6,01^{\mathrm{c}}$ & $5,53^{\mathrm{e}}$ & $4,34^{\mathrm{d}}$ & $5,26^{e}$ \\
\hline
\end{tabular}

Keterangan : Angka yang ditandai dengan huruf yang berbeda menunjukkan ada beda nyata

Hasil penilaian organoleptik surimi maupun gel surimi manyung dapat dilihat pada Tabel 3 sampai 6 . Tabel 3 menunjukkan bahwa nilai skoring kenampakan, warna, dan bau surimi manyung cenderung meningkat dengan meningkatnya frekuensi pencucian. Nilai tertinggi diperoleh pada surimi yang mengalami pencucian daging lumat empat dan lima kali. Perlakuan pencucian daging lumat empat kali tidak berbeda nyata $(\alpha=0,05)$ dengan perlakuan pencucian daging lumat lima kali sehingga pencucian daging lumat empat kali merupakan perlakuan terbaik sebab mempunyai nilai skoring tertinggi. Pada perlakuan tersebut dihasilkan kenampakan surimi paling bersih, warna putih, dan tidak berbau sebab pada perlakuan pencucian daging lumat empat kali lemak, darah, kotoran, dan senyawa-senyawa berbau lainnya sebagian besar sudah terbuang pada proses penirisan daging lumat. Tabel 4 menunjukkan bahwa nilai skoring kenampakan, warna, dan bau gel surimi manyung juga mempunyai pola yang mirip dengan surimi sebelum membentuk gel (Tabel 3).

Tabel 5 menunjukkan bahwa nilai hedonik kenampakan, warna, bau, dan kesukaan keseluruhan surimi manyung juga cenderung meningkat dengan meningkatnya frekuensi pencucian. Hal ini berarti bahwa frekuensi pencucian daging lumat dapat meningkatkan penerimaan panelis terhadap surimi manyung. Adanya pencucian daging lumat akan menghilangkan sebagian besar kotoran, darah, lemak dan senyawa-senyawa berbau sehingga dapat meningkatkan penerimaan panelis. Kesukaan keseluruhan surimi meningkat dari cukup tidak suka (tanpa pencucian daging lumat) menjadi netral (pencucian daging lumat satu kali dan dua kali) dan cukup suka (pencucian daging lumat empat dan lima kali). Penerimaan panelis pada perlakuan pencucian daging lumat empat dan lima kali adalah cukup suka. Pada perlakuan tersebut surimi manyung mempunyai kenampakan yang lebih bersih, lebih putih, 
dan lebih tidak berbau dari pada perlakuan pencucian daging lumat satu, dua, dan tiga kali. Pada Tabel 6 dapat dilihat bahwa nilai hedonik kenampakan, warna, dan bau gel surimi manyung juga mempunyai pola yang mirip dengan surimi sebelum membentuk gel (Tabel 5).

\section{Kesimpulan dan Saran}

\section{Kesimpulan}

a. Manyung (Arius spp.) dapat diolah menjadi surimi dan tergolong jenis ikan penghasil surimi dengan kekuatan gel yang tinggi.

b. Pencucian daging lumat pada pengolahan surimi manyung meningkatkan mutu surimi

c. Surimi manyung yang dibuat dengan pencucian daging lumat empat kali menghasilkan surimi yang bermutu baik (nilai uji lipat "A") dengan nilai skoring tertinggi yaitu kenampakan 6,20 , warna 6,25 , dan bau 5,66 dan cukup disukai panelis, dengan kadar protein kasar $17,29 \%$, lemak $1,13 \%$, dan air $79,86 \%$.

d. Pencucian daging lumat satu, dua, tiga, empat, dan lima kali pada pengolahan surimi tidak menurunkan nilai gizinya.

\section{Saran}

a. Perlu tindak lanjut penelitian tentang pengolahan surimi manyung menjadi produk jadi.

b. Perlu penelitian lebih lanjut tentang faktor-faktor yang mempengaruhi efisiensi pencucian daging lumat pada pengolahan surimi antara lain rasio antara daging lumat dengan air pencuci, temperatur pencucian, dan lama pencucian.

c. Perlu penelitian tentang variasi cryoprotectant dengan jumlah siklus pencucian daging lumat yang baik untuk pengolahan surimi manyung.

\section{Ucapan Terima Kasih}

Penghargaan dan terima kasih disampaikan kepada Universitas Gadjah Mada melalui Lembaga Penelitian, yang telah memberikan bantuan biaya untuk pelaksanaan penelitian ini. Terima kasih juga disampaikan kepada Saudara Sriyanto atas bantuannya dalam melaksanakan penelitian.

\section{Daftar Pustaka}

Anonim. 2000. Studi rencana pembangunan pelabuhan perikanan di Daerah Istimewa Yogyakarta. laporan penelitian. dinas perikanan DIY PUSTEK kelautan UGM. Yogyakarta.

AOAC. 1970. Official methods of analysis of the association of official analytical chemists. association of official analytical chemists. Washington, DC.

Fennema, O.R. 1985. Principle of Food Science. Post I. Food Chemistry. Marcell Dekker Inc. New York.

Gomez, K.A. dan Gomez, A.A. 1995. Statistical procedures for agricultural research (Prosedur statistik untuk penelitian pertanian, Alih bahasa E. Syamsuddin, J.S. Baharsyah, dan A.H. Nasution). UI Press. Jakarta.

Hanafiah, T.A.R. dan Malawat, S. 1995. Studi pembuatan surimi ikan campuran dari hasil tangkapan samping pukat udang dalam prosiding simposium perikanan indonesia I. buku II. Jakarta. 84-93.

Hennigar, C.J., Buck, E.M., Hultin, H.O., Peleg, M. and Vareltzism, K.1998. Effect of washing and sodium chloride on mechanical properties of fish muscle. J. Food Sci. 35(3): 963-964.

Huda, N., Abdullah, A., dan Babji, A.S.1999. Halal issues in processing 
surimi and surimi-based food products. INFOFISH International. 5: 45-49.

Irianto, B. 1990. Teknologi surimi: salah satu cara memperoleh nilai tambah ikan-ikan yang kurang dimanfaatkan. J. Litbang Pertanian IX(2): 32-37.

Kartika, B., Astuti, P. dan Supartono, W. 1988. Pedoman uji inderawi. PAU pangan dan gizi UGM. Yogyakarta.

Soekarto. 1985. Penilaian organoleptik untuk industri pangan dan hasil pertanian. Bhratara karya aksara. Jakarta.

Sudarmadji, S., Haryono, B., dan Suhardi.1996. Analisa bahan makanan dan pertanian. Liberty-PAU pangan dan gizi UGM. Yogyakarta.

-------. 1997. Prosedur analisa untuk bahan makanan dan pertanian. Liberty. Yogyakarta.

Suyuti, N. dan Tambunan, R. 1974. Penelitian pendahuluan pemanfaatan "trashfish". Lap. Penel. LPTP. 2: 51-67. 